Original Research Paper

\title{
HUBUNGAN ASUPAN LEMAK TERHADAP PERSENTASE LEMAK TUBUH MAHASISWA FAKULTAS KEDOKTERAN UNIVERSITAS TADULAKO ANGKATAN 2019
}

\section{Mega Mutia Rahman ${ }^{1}$, Nur Asmar Salikunna ${ }^{2 *}$, Sumarni $^{3}$, Rosa Dwi Wahyuni ${ }^{4}$ Rahma Badaruddin ${ }^{2}$, Moh Zainul Ramadhan ${ }^{2}$, Afriani Arief ${ }^{5}$}

\author{
${ }^{1}$ Mahasiswa Kedokteran, Fakultas Kedokteran, Universitas Tadulako. \\ ${ }^{2}$ Departemen Fisiologi, Fakultas Kedokteran, Universitas Tadulako \\ ${ }^{3}$ Bagian Ilmu Gizi, Fakultas Kedokteran, Universitas Tadulako \\ ${ }^{4}$ Departemen Patologi Klinik, Fakultas Kedokteran, Universitas Tadulako \\ ${ }^{5}$ Dinas Pendidikan Kota Gorontalo
}

\section{Email Corresponding: \\ nurrasma@yahoo.co.id}

\section{Kata Kunci :}

Asupan Lemak, Persentase Lemak Tubuh, Food Recall 24 Hours, dan Bioelectrical Impedance Analysis

\section{Keywords:}

Fat Intake, Body Fat Percentage, 24 Hours Food Recall, and

Bioelectrical Impedance Analysis
Page : $21-29$

Di Indonesia, masalah gizi berlebih menjadi hal yang penting, karena overweight dan obesitas sejak dini akan memiliki risiko tinggi terkena penyakit-penyakit metabolik. Mengonsumsi makanan yang tinggi lemak, akan menyebabkan penyimpanan lemak berlebih dalam tubuh, sehingga menyebabkan resiko yang kurang baik bagi tubuh. Hal tersebut menunjukkan pentingnya memantau asupan lemak dan persentase lemak tubuh sejak dini. Penelitian ini bertujuan untuk Mengetahui hubungan asupan lemak terhadap persentase lemak tubuh pada mahasiswa Fakultas Kedokteran Universitas Tadulako Angkatan 2019. Penelitian ini merupakan penelitian deskriptif analitik dengan desain penelitian cross sectional. Teknik pengambilan sampel dengan metode total sampling. Asupan lemak diperoleh melalui Food Recall 24 Hours selama 7 hari dan dianalisis menggunakan aplikasi Nutrisurvey. Persentase lemak tubuh yang diukur menggunakan Bioelectrical Impedance Analysis (BIA). Analisis bivariat menggunakan uji Spearman Rank Correlation. Berdasarkan hasil yang didapatkan dengan menggunakan uji Spearman Rank Correlation dengan nilai signifikansinya $\mathrm{p}=0,002(\mathrm{p}<0,05)$, artinya terdapat korelasi antara asupan lemak dan persentase lemak tubuh. Correlation Coefficien sebesar 0,585, artinya menandakan adanya hubungan yang kuat antara asupan lemak dan persentase lemak tubuh. Nilai rerata asupan SFA $(32,24 \pm 6,57)$, MUFA $(15,55 \pm 3,01)$, PUFA $(12,86 \pm 4,93)$ dan Kolesterol $(277,51 \pm 138,8)$. Berdasarkan hasil tersebut, nilai rerata asupan asam lemak jenuh (SFA) lebih besar dibandingkan asupan asam lemak tidak jenuh tunggal (MUFA) maupun asupan asam lemak tidak jenuh ganda (PUFA). Hasil yang didapatkan bahwa terdapat korelasi positif yang kuat antara asupan lemak dan persentase lemak tubuh, Mahasiswa Fakultas Kedokteran Universitas Tadulako Angkatan 2019.

\section{Tadulako University,}

Published by:

Managed by Faculty of Medicine.

Email: healthytadulako@gmail.com

Phone (WA): +6285242303103

Address:

Jalan Soekarno Hatta Km. 9. City of

Palu, Central Sulawesi, Indonesia

\section{ABSTRACT}

In Indonesia, the problem of excess nutrition is important, because overweight and obesity from an early age will have a high risk of developing metabolic diseases. Eating foods that are high in fat will cause excess fat storage in the body, thus causing risks that are not good for the body. It shows the importance of monitoring fat intake and body fat percentage early on. This research aims to determine the relationship between fat intake and the body fat percentage of students at the Medical Faculty of Tadulako University, Class of 2019. This research was a descriptive-analytic with a cross sectional research design. The sampling technique was total sampling. Fat intake was obtained through Food Recall 24 Hours for 7 days and analyzed using Nutrisurvey application. The body fat percentage was measured using Bioelectrical Impedance Analysis (BIA). The bivariate analysis used the Spearman Rank Correlation test. Based on the results 


\begin{abstract}
obtained using the Spearman Rank Correlation test with a significance value of $p$ $=0.002(p<0.05)$, it means that there is a correlation between fat intake and body fat percentage. The coefficient correlation is 0.585 , which means that it indicates a strong relationship between fat intake and body fat percentage. The average value of SFA intake are (32.24 \pm 6.57$)$, MUFA (15.55 \pm 3.01$)$, PUFA (12.86 \pm 4.93$)$, and cholesterol (277.51 \pm 138.8$)$. Based on these results, the average value of Saturated Fatty Acid (SFA) intake is greater than Monounsaturated Fatty Acid (MUFA) and Polyunsaturated Fatty Acid (PUFA) intake. The results obtained show that there is a strong positive correlation between fat intake and body fat percentage of students at Medical Faculty, Tadulako University, and Class of 2019.
\end{abstract}

\section{PENDAHULUAN}

Di Indonesia, 13,5\% orang dewasa usia 18 tahun ke atas kelebihan berat badan, sementara itu $28,7 \%$ mengalami obesitas (IMT $\geq 25)$ dan berdasarkan indikator RPJMN 2015-2019 sebanyak $15,4 \%$ mengalami obesitas (IMT $\geq 27)^{1}$. Overweight dan obesitas mempengaruhi usia harapan hidup seseorang. Overweight dan obesitas merupakan suatu kelainan yang ditandai dengan adanya peningkatan lemak tubuh secara berlebih ${ }^{2}$. Seseorang yang mengalami overweight dan obesitas sejak dini akan memiliki risiko tinggi terkena penyakit-penyakit metabolik ${ }^{3}$. Pengukuran berat badan menjadi hal yang sangat penting karena prevalensi obesitas pada orang dewasa ditahun 2013 mencapai 19,7\% pada laki-laki dan $32,9 \%$ pada perempuan ${ }^{4}$.

Lemak merupakan suatu zat gizi sebagai penyumbang kalori terbesar dalam makanan, yaitu 1 gr lemak akan menghasilkan 9 kalori. Mengonsumsi makanan yang tinggi akan lemak atau atau terlalu banyak mengkonsumsi makanan sumber energi apapun, akan menyebabkan penyimpanan lemak berlebih dalam tubuh. Makanan yang berlemak akan memberikan sumbangan energi yang lebih besar karena makanan berlemak mengandung dua kali lebih banyak kalori dibandingkan dengan protein ${ }^{5}$.

Persentase lemak tubuh adalah persentase massa lemak dari berat badan total yang diukur dengan alat Bioelectric Impedance Analyzer (BIA) dan dinyatakan dalam satuan $\%$. Nilai persentase lemak tubuh dikategorikan menjadi underfat: $30-34 \%$ dan obesitas $>35 \%$. Pengukuran persentase lemak tubuh adalah sesuatu yang diperlukan untuk memantau lemak tubuh seseorang, obesitas dan untuk pengaturan diet dalam program pelayanan kesehatan. Pendistribusian lemak tubuh terdiri dari lemak subkutan (lemak dibawah kulit) dan lemak visceral (lemak daerah perut $)^{7}$. Persentase lemak tubuh dapat menggambarkan tingkat obesitas lebih baik dari indeks massa tubuh (IMT) meski tidak terlalu sensitif terhadap perubahan komposisi tubuh jangka pendek ${ }^{8}$. Obesitas terjadi akibat adaya peningkatan lemak yang berlebihan dan dapat berdapak kurang baik bagi kesehatan. Seseorang yang obesitas memiliki kadar lemak berlebihan sehingga semakin tinggi pula penyimpanan lemak di jaringan adiposa dan dapat menghasilkan berat badan yang lebih besar dari 20\% dibandingkan dengan kodisi normal. Peningkatan profil lipid yang terjadi pada seseorang yang mengalami obesitas diakibatkan karena penurunan adiponektin. Profil lipid yang meningkat terutama kolesterol, hal tersebut dapat mengganggu pembentukan memori. Pembentukan memori jangka pendek maupun panjang sangat diperlukan untuk menunjang prestasi akademik ${ }^{9}$.

Makanan yang berlebih di dalam tubuh akan disimpan dalam bentuk lemak yang terletak pada jaringan di bawah kulit, jantung, paru-paru, ginjal, otot dan organ tubuh lainnya. Simpanan lemak dalam tubuh dapat digunakan menjadi cadangan energi ${ }^{10}$. 
Rendahnya pengeluaran energi oleh tubuh dapat disebabkan karena rendahnya metabolisme tubuh, aktivitas fisik, dan efek termogenesis makanan yang ditentukan berdasarkan komposisi makanan. Efek termogenesis dari lemak lebih rendah dibandingkan dengan karbohidrat dan protein yaitu sebanyak (3\% dari total energi yang dihasilkan lemak), sedangkan karbohidrat sebanyak ( $6-7 \%$ dari total energi yang dihasilkan karbohidrat) dan protein sebanyak (25\% dari total energi yang dihasilkan protein). Hal tersebut menunjukkan pentingnya pola makan dan asupan makanan dalam terjadinya obesitas ${ }^{11}$.

Merujuk pada pernyataan di atas, diperlukan adanya penelitian untuk mengetahui hubungan asupan lemak terhadap persentase lemak tubuh pada Mahasiswa Fakultas Kedokteran Universitas Tadulako Angkatan 2019.

\section{BAHAN DAN CARA}

Pada penelitian ini, jenis penelitian yang dipakai adalah jenis penelitian deskriptif analitik dengan rancangan cross sectional. Metode yang digunakan adalah metode survey dengan menggunakan teknik pengumpulan data menggunakan food recall 24 hours yaitu dengan mencatat makanan yang dikonsumsi serta aktivitas yang dilakukan selama 24 jam dimaksudkan untuk dapat mengetahui hubungan asupan lemak terhadap presentase lemak tubuh pada Mahasiswa Fakultas Kedokteran Universitas Tadulako Angkatan 2019.

Penelitian ini dilakukan di Fakultas Kedokteran Universitas Tadulako. Penelitian ini dilakukan pada Agustus 2020. Populasi pada penelitian ini adalah Mahasiswa Fakultas Kedokteran Universitas Tadulako Angkatan 2019. Sampel dalam penelitian ini adalah Mahasiswa Angktan 2019 Fakultas Kedokteran Universitas Tadulako yang memenuhi kriteria inklusi dan ekslusi. Pengambilan sampel pada penelitian ini menggunakan Total Sampling. Didapatkan 25 sampel berdasarkan kriteria inklusi.

Variabel bebas pada penelitian ini adalah asupan lemak. Variabel terikat pada penelitian ini adalah persentase lemak tubuh. Data yang diambil dalam penelitian ini antara lain data identitas sampel, data antropometri meliputi tinggi badan, berat badan dan persentase lemak tubuh, data asupan lemak, serta data usia. Pengambilan sampel diawali dengan melakukan pengumpulan data meliputi identitas sampel, pengukuran tinggi badan menggunakan microtoise dengan ketelitian $200 \mathrm{~cm}$, dan pengukuran berat badan dengan menggunakan Bioelectrical Impedance Analysis (BIA) Tanita Body Composition Analyzer BC-541.

Asupan lemak, didefinisikan sebagai jumlah asupan lemak yang dikomsumsi seharihari diperoleh melalui Food Recall 24 Hours (Prinsip dari metode ini yaitu dilakukan dengan mencatat jenis dan jumah bahan makanan yang dikonsumsi pada periode 24 jam). Data yang diperoleh akan dikonversikan ke dalam satuan gram dan dihitung besar asupan lemak, menggunakan program nutrisurvey kemudian dibandingkan dengan Angka Kecukupan Gizi (AKG) individu. Asupan lemak dikatakan lebih (>110\% AKG), cukup (90-110\% AKG) dan kurang (<90\% AKG).

Pengukuran persentase lemak tubuh dimulai dengan memasukan data yang perlu dimasukkan kedalam BIA meliputi BB, TB, usia, jenis kelamin dan aktifitas fisik. Selanjutnya probandus berdiri di atas Bioelectrical Impedance Analysis (BIA) tanita Body Composition Analyzer BC-541, setelah itu menulis data yang didapatkan. Hasil yang didapatkan dinyatakan dalam persen (\%). Obese $>35 \%$, Overfat $>31 \%$ s/d $\leq 35 \%$, 
Normal, $\geq 16 \% \mathrm{~s} / \mathrm{d} \leq 31 \%$, dan Underfat, jika $<16 \%$.

Analisis Univariat dilakukan untuk mendeskripsikan dan menganalisis masingmasing variabel. Analisis bivariat digunakan untuk mengetahui hubungan asupan lemak dengan persentase lemak tubuhtruasi menggunakan uji Spearman Rank Correlation, dilakukan dengan teknik komputerisasi, jika nilai signifikansi $\mathrm{P}<0,05$ maka berkorelasi.

\section{HASIL}

\section{Karakteristik Umum Subjek}

Penelitian ini dilakukan di Fakultas Kedokteran Universitas Tadulako pada bulan Agustus 2020. Subjek penelitian merupakan mahasiswi Fakultas Kedokteran Angkatan 2019, yang berusia 19-21 tahun, dan berdomisili di Palu, berjumlah 25 orang.

\section{Tabel 1. Karakteristik Subjek Berdasarkan Umur, Tinggi Badan dan Berat Badan.}

\begin{tabular}{lcc}
\hline \multirow{2}{*}{ Variabel } & \multicolumn{2}{c}{ Perempuan $(\mathbf{n = 2 5})$} \\
\cline { 2 - 3 } & Rata-rata & $\begin{array}{c}\text { Standar } \\
\text { Deviasi }\end{array}$ \\
\hline Umur & 19,48 & 0,714 \\
Tinggi Badan (m) & 1,5671 & 0,059 \\
Berat Badan (kg) & 52,56 & 12,318 \\
\hline
\end{tabular}

Keseluruhan subjek berjumlah 25 mahasiswa perempuan, berumur 19-21 tahun, dengan rerata umur subjek 19,48 (SD 0,714), rerata tinggi badan subjek 1,5671 (SD 0,059) $\mathrm{m}$, sedangkan rerata berat badan 52,56 ( $S D$ 12,318) kg. Data tersebut lebih lengkapnya dapat dilihat pada tabel berikut ini (Tabel 1).

\section{Karakteristik Responden Berdasarkan} Data Asupan Lemak dengan Food Recall 24 Hours Selama 7 Hari

Distribusi asupan lemak pada saat dilakukannya Food Recall 24 Hours Selama 7
Hari, didapatkan hasil yang bervariasi sesuai dengan yang tertera pada (Tabel 2).

Tabel 2. Distribusi Asupan Lemak Responden Pada Mahasiswa Fakultas Kedokteran Universitas Tadulako Angkatan 2019.

\begin{tabular}{lll}
\hline Asupan Lemak & Frekuensi & Presentase \\
\hline Lebih & 7 & $28 \%$ \\
\hline Cukup & 18 & $72 \%$ \\
\hline Total & $\mathbf{2 5}$ & $\mathbf{1 0 0 \%}$ \\
\hline
\end{tabular}

Berdasarkan dari tabel 2. menunjukkan bahwa dari 25 responden, paling banyak responden yang mempunyai asupan lemak yang cukup yaitu berjumlah 18 responden atau $72 \%$ yaitu berkisar antara 90-110\% AKG, sedangkan untuk kelompok responden dengan asupan lemak yang berlebih yaitu berjumlah 7 responden atau $28 \%$, yaitu $>110 \%$ AKG.

Nilai rerata, standar deviasi, minimal dan maksimal, asupan SFA, MUFA, PUFA, Kolesterol dan IMT pada responden.

Responden dengan nilai rerata, standar deviasi, minimal dan maksimal untuk asupan SFA, MUFA, PUFA, Kolesterol dan IMT seperti pada (Tabel. 3)

Tabel 3 Nilai rerata, standar deviasi, minimal dan maksimal, asupan SFA, MUFA, PUFA, Kolesterol pada Mahasiswa Fakultas Kedokteran Angkatan 2019

\begin{tabular}{llll}
\hline Variabel & \multicolumn{3}{c}{$\begin{array}{c}\text { Perempuan } \\
\mathbf{n = 2 5}\end{array}$} \\
\hline & Mean \pm SD & Min & Maks \\
\hline SFA & $32,24 \pm 6,57$ & 18,4 & 43 \\
\hline MUFA & $15,55 \pm 3,01$ & 7,2 & 21,8 \\
\hline PUFA & $12,86 \pm 4,93$ & 5,9 & 23,2 \\
\hline Kolesterol & $277,51 \pm 138,8$ & 99,7 & 799,8 \\
\hline Catatan=SFA= saturated & fatty & acid/asam \\
lemak jenuh, MUFA= monounsaturated fatty
\end{tabular}


acid/asam lemak tidak jenuh tunggal, PUFA= polyunsaturated fatty acid/asam lemak tidak jenuh ganda.

Berdasarkan tabel 3 hasil yang
didapatkan nilai rerata asupan SFA
$(32,24 \pm 6,57)$, MUFA $(15,55 \pm 3,01)$, PUFA
$(12,86 \pm 4,93)$ dan Kolesterol $(277,51 \pm 138,8)$.

Dari hasil tersebut, terlihat Nilai rerata asupan asam lemak jenuh (SFA) lebih besar dibandingkan asupan asam lemak tidak jenuh tunggal (MUFA) maupun asupan asam lemak tidak jenuh ganda (PUFA). Sedangkan untuk asupan kolesterol nilai reratanya $(277,51 \pm 138,8)$ atau $\leq 300 \mathrm{mg} /$ hari dalam kategori normal.

\section{Karakteristik Responden Berdasarkan Data Persentase Lemak Tubuh}

Persentase lemak tubuh dikategorikan Obese, Overfat, Normal, dan Underfat. Distribusi data responden bervariasi, tetapi tidak ditemukan adanya kategori Underfat terhadap responden yang diteliti, seperti tertera pada (Tabel 4).

\begin{tabular}{lll}
\hline $\begin{array}{l}\text { Persentase } \\
\text { Lemak Tubuh }\end{array}$ & Frekuensi & Presentase \\
\hline Obese & 5 & $20 \%$ \\
\hline Overfat & 2 & $8 \%$ \\
\hline Normal & 18 & $72 \%$ \\
\hline Total & 25 & $100 \%$ \\
\hline
\end{tabular}

Berdasarkan dari tabel 4. dapat diketahui bahwa dari 25 responden, paling banyak responden mempunyai persentase lemak tubuh dalam batas normal yaitu berjumlah 18 responden atau $72 \%$, yaitu berkisar $\geq 16 \%$ s/d $\leq 31 \%$. Sedangkan untuk persentase lemak tubuh dengan kategori Obese, yaitu berjumlah 5 responden atau 20\%, yaitu $>35 \%$, dan distribusi yang paling sedikit yaitu kelompok responden dengan persentase lemak tubuhnya kategori Overfat yaitu berjumlah 2 responden atau $8 \%$, yaitu berkisar $>31 \% \mathrm{~s} / \mathrm{d} \leq 35 \%$.

\section{Hubungan Asupan Lemak Tubuh Terhadap Persentase Lemak Tubuh}

Responden dengan data asupan lemak dan persentase lemak tubuh yang dianalisis, untuk melihat adanya korelasi diantara variabel tersebut, seperti pada (Tabel 5).

Tabel 5. Hubungan Asupan Lemak Terhadap Persentase Lemak Tubuh

\begin{tabular}{|c|c|c|c|c|}
\hline \multicolumn{5}{|l|}{ Correlations } \\
\hline & & & $\begin{array}{l}\text { PERSENTASE } \\
\text { LEMAK } \\
\end{array}$ & $\begin{array}{l}\text { ASUPAN } \\
\text { LEMAK } \\
\end{array}$ \\
\hline \multirow[t]{6}{*}{ Spearman's rho } & \multirow[t]{3}{*}{$\begin{array}{l}\text { PERSENTASE } \\
\text { LEMAK }\end{array}$} & $\begin{array}{l}\text { Correlation } \\
\text { Coefficient }\end{array}$ & 1.000 & $.585^{* *}$ \\
\hline & & Sig. (2-tailed) & . & .002 \\
\hline & & $\mathrm{N}$ & 25 & 25 \\
\hline & \multirow[t]{3}{*}{$\begin{array}{l}\text { ASUPAN } \\
\text { LEMAK }\end{array}$} & $\begin{array}{l}\text { Correlation } \\
\text { Coefficient }\end{array}$ & $.585^{* * *}$ & 1.000 \\
\hline & & Sig. (2-tailed) & .002 &. \\
\hline & & $\mathrm{N}$ & 25 & 25 \\
\hline
\end{tabular}


Pada subjek, didapatkan hubungan korelasi positif antara asupan lemak dengan persentase lemak tubuh yang menunjukkan semakin tinggi asupan lemak semakin tinggi pula persentase lemak tubuh. Berdasarkan hasil yang didapatkan dengan menggunakan uji Spearman Rank Correlation dengan nilai signifikansinya adalah sebesar $\mathrm{p}<0,05$ $(\mathrm{p}=0,002)$, yang artinya terdapat korelasi antara asupan lemak dan persentase lemak tubuh. Selanjutnya dengan Correlation Coefficien sebesar 0,585 yang artinya nilai ini menandakan adanya hubungan yang kuat antara asupan lemak dan persentase lemak tubuh (Tabel 5).

\section{PEMBAHASAN}

\section{Karakteristik Subjek}

Penelitian ini dilakukan pada Mahasiswa Fakultas Kedokteran Universitas Tadulako Angkatan 2019. Tujuan penelitian ini yaitu untuk mengetahui apakah terdapat hubungan asupan lemak terhadap persentase lemak tubuh, pada Mahasiswa Fakultas Kedokteran Universitas Tadulako Angkatan 2019. Penelitian ini dilakukan khusus untuk mahasiswa perempuan yang berdomisili di Palu, dengan pemberian formulir food recall 24 hours pada responden untuk pengambilan data asupan lemak selama 7 hari dan melakukan pemeriksaan terhadap persentase lemak tubuh secara langsung menggunakan timbangan BIA tanita Body Composition Analyzer BC-541. Dari penelitian tersebut, didapatkan total sampel sebanyak 25 orang, kemudian pemilihan sampel berdasarkan kriteria inklusi dan ekslusi peneliti. Data dari setiap sampel tersebut dimasukkan ke dalam program SPSS untuk diolah lebih lanjut.

Dalam penelitian ini, responden yang menjadi kriteria inklusi adalah perempuan berusia 19-22 tahun, yang berdomisili palu. Alasan peneliti memilih perempuan karena pada perempuan penyebaran lemak tubuh spesifik mulai timbul sejak masa pubertas dan biasanya tersebar di daerah perut bagian bawah, paha, payudara dan sekitar alat genital. Berbeda dengan laki-laki, karena pada wanita memiliki penyebaran pola distribusi lemak yang spesifik sejak masa pubertas, dan juga dipengaruhi oleh hormonal, bahwa persentase lemak tubuh perempuan lebih tinggi dibandingkan laki-laki.

Hasil analisa univariat menunjukkan bahwa Mahasiswa Fakultas Kedokteran Universitas Tadulako Angkatan dengan asupan lemak yang cukup sebanyak 18 orang (72\%), dan untuk kelompok responden dengan asupan lemak yang berlebih yaitu sebanyak 7 orang (28\%). Sedangkan untuk persentase lemak tubuh, paling banyak responden mempunyai persentase lemak tubuh dalam batas normal yaitu berjumlah 18 orang (72\%). Sedangkan untuk persentase lemak tubuh dengan kategori Obese, yaitu berjumlah 5 orang (20\%), dan distribusi yang paling sedikit yaitu kelompok responden dengan persentase lemak tubuhnya kategori Overfat yaitu berjumlah 2 orang (8\%).

Dalam studi epidemiologi manusia, telah ditunjukkan bahwa asupan makanan tinggi lemak yang sebagian besar mencakup omega-6 dan SFA dikaitkan dengan kinerja yang lebih buruk pada tugas kognitif. Selanjutnya, penelitian telah menunjukkan bahwa diet yang mengandung sebagian besar PSAK dan TFA dikaitkan dengan peningkatan risiko penyakit Alzheimer (AD). Di sisi lain, diet rendah lemak yang terdiri dari asam lemak omega-3 memiliki efek perlindungan terhadap penurunan kognitif pada subjek lansia yang sehat. Juga telah ditentukan bahwa konsumsi tinggi lemak total, SFA, dan kolesterol dikaitkan dengan peningkatan kolesterolemia, risiko penyakit kardiovaskular, dan gangguan fungsi intelektual, menunjukkan bahwa kadar kolesterol yang bersirkulasi terkait erat dengan 
kinerja kognitif pada manusia ${ }^{12}$. Sedangkan asupan lemak yang rendah akan menyebabkan terjadinya penurunan massa tubuh dan gangguan pada penyerapan vitamin larut lemak. Ketidakseimbangan tingkat konsumsi zat gizi makro seperti energi, karbohidrat, lemak dan protein terhadap kebutuhan tubuh secara berkepanjangan dapat mempengaruhi terjadinya perubahan pada jaringan dan massa tubuh yang akan berdampak pada penurunan berat badan (berat badan kurang) ${ }^{13}$. Jika konsumsi lemak kurang dapat menyebabkan gangguan pertumbuhan dan penurunan imunitas terhadap penyakit ${ }^{14}$.

Berdasarkan hasil penelitian yang telah dilakukan menunjukkan bahwa terdapat hubungan antara asupan lemak dengan persentase lemak tubuh dengan nilai $\mathrm{p}=0,002$ atau nilai $\mathrm{p} \leq 0,05$. Dimana diketahui bahwa responden yang memiliki persentase lemak tubuh normal lebih banyak memiliki asupan lemak yang cukup yaitu 18 (72\%), karena dengan mengonsumsi lemak yang cukup akan menghindari adanya penumpukkan lemak yang berlebih, sehingga dapat menyebabkan peningkatan terhadap persentase lemak tubuh. Dimana dari hasil penelitian didapatkan banyak responden yang konsumsi lemaknya terkontrol atau berada dalam angka kecukupan lemaknya. Namun masih ada beberapa responden yang konsumsi lemak melebihi angka kecukupan gizi, yaitu sekitar 7 responden $(28 \%)$.

Dari Tabel 5. hubungan asupan lemak terhadap persentase lemak tubuh, hasil uji bivariat diartikan bahwa terdapat korelasi positif antara asupan lemak dan persentase lemak tubuh. Selanjutnya dengan Correlation Coefficien sebesar 0,585 yang artinya nilai ini menandakan adanya hubungan yang kuat antara asupan leman dan persentase lemak tubuh. Hal ini sejalan dengan penelitian yang dilakukan oleh Amelia ${ }^{15}$, hasil analisis data asupan energi dan persen lemak tubuh didapatkan nilai $r=0,228$ dan $p=0,080$ yang menunjukkan adanya arah korelasi positif dengan kekuatan yang lemah antara asupan energi dengan persen lemak tubuh, tetapi tidak ada hubungan yang signifikan antara asupan energi dengan persen lemak tubuh. Korelasi positif mengartikan bahwa semakin tinggi asupan energi maka persen lemak tubuh akan semakin tinggi. Disini dapat dikaitkan karena lemak sebagai penyumbang kalori terbesar dalam makanan, yaitu 1 gr lemak akan menghasilkan 9 kalori. Jadi bisa searah, karena semakin tinggi asupan lemak dalam tubuh, semakin tinggi pula persentase lemak tubuh seseorang.

Berdasarkan penelitian dari Rachmawati ${ }^{16}$, didapatkan hasil asupan lemak $37,1 \%$ penari tergolong defisit tingkat berat. Sebagian besar penari memiliki aktivitas fisik yang berat $(91,9 \%)$ dan persentase lemak tubuh yang normal $(87,1 \%)$. Terdapat hubungan antara asupan energi, karbohidrat, lemak dan aktivitas fisik dengan gangguan siklus menstruasi $(\mathrm{p}<0,05)$. Dari hasil penelitian tersebut, dapat dikatan bahwa seseorang yang memiliki aktivitas fisik yang berat dapat mempunyai persentase lemak tubuh yang normal. Disisi lain hasil asupan lemaknya $37 \%$ tergolong defisit berat, tetapi untuk persentase lemak tubuhnya terdapat $8,1 \%$ subjek yang memiliki persentase lemak tubuh dengan kategori underfat. Sehingga disini dapat dikatakan aktivitas fisik dapat juga mempengaruhi persentase lemak tubuh seseorang.

Dari 25 responden yang asupan lemaknya cukup terdapat 18 orang (72\%), dengan kisaran asupan lemak sebesar 90$110 \%$ yang sesuai dengan angka kecukupan gizi, dan untuk kelompok responden yang memiliki asupan lemak yang berlebih terdapat 7 orang (28\%) karena asupan lemaknya $>110 \%$ yang sesuai dengan angka kecukupan gizi untuk kategori asupan lemak yang lebih. 
Dari hasil penelitian setelah dilakukan food recall 24 hours selama 7 hari, tidak ditemukan responden yang memiliki asupan lemak dengan defisit berat. Dalam hal ini, dapat dilihat juga pada pengukuran persentase lemak tubuh 25 responden, yang memiliki kategori normal yaitu sebesar 18 orang (72\%), dengan kisaran persentase lemak $\geq 16 \%$ s/d $\leq 31 \%$, sedangkan untuk persentase lemak tubuh dengan kategori Obese, yaitu berjumlah 5 responden atau $20 \%$ dengan kisaran persentase lemak $>35 \%$, dan distribusi yang paling sedikit yaitu kelompok responden dengan persentase lemak tubuhnya kategori Overfat yaitu berjumlah 2 responden atau $8 \%$, dengan kisaran persentase lemak $>31 \%$ s/d $\leq 31 \%$. Hal ini menunjukkan bahwa asupan lemak dan persentase lemak tubuh memiliki korelasi yang positif.

Berdasarkan tabel 3 hasil yang
didapatkan nilai rerata asupan SFA
$(32,24 \pm 6,57)$, MUFA $(15,55 \pm 3,01)$, PUFA
$(12,86 \pm 4,93)$ dan Kolesterol $(277,51 \pm 138,8)$.
Sedangkan untuk asupan kolesterol nilai reratanya $(277,51 \pm 138,8)$ atau $\leq 300 \mathrm{mg} / \mathrm{hari}$ dalam kategori normal. Dari hasil tersebut, terlihat bahwa Nilai rerata asupan asam lemak jenuh (SFA) lebih besar dibandingkan asupan asam lemak tidak jenuh tunggal (MUFA) maupun asupan asam lemak tidak jenuh ganda (PUFA).

\section{KESIMPULAN DAN SARAN}

Berdasarkan hasil penelitian yang telah dilakukan pada 25 responden maka dapat disimpulkan bahwa:

1. Asupan lemak pada Mahasiswa Fakultas Kedokteran Universitas Tadulako Angkatan 2019, paling banyak memiliki asupan lemak dengan kategori cukup yaitu berkisar antara 90-110\% AKG.

2. Persentase lemak tubuh pada Mahasiswa Fakultas Kedokteran Universitas Tadulako Angkatan 2019, memiliki persentase lemak tubuh yang normal yaitu berkisar antara $\geq 16 \% \mathrm{~s} / \mathrm{d} \leq 31 \%$.

3. Nilai rerata asupan asam lemak jenuh (SFA) lebih besar dibandingkan asupan asam lemak tidak jenuh tunggal (MUFA) maupun asupan asam lemak tidak jenuh ganda (PUFA).

4. Hasil yang didapatkan bahwa terdapat korelasi antara asupan lemak dan persentase lemak tubuh. Selanjutnya dengan Correlation Coefficien sebesar 0,585 yang artinya nilai ini menandakan adanya hubungan yang kuat antara asupan lemak dan persentase lemak tubuh pada Mahasiswa Fakultas Kedokteran Universitas Tadulako Angkatan 2019.

Sebagai Saran Bagi Mahasiswa Fakultas Kedokteran Universitas Tadulako Angkatan 2019, untuk selalu mengontrol asupan lemak yang berlebih dan selalu persentase lemak tubuh agar tetap stabil, maka disarankan untuk mengonsumsi lemak sebesar 65 gr/hari untuk perempuan dengan usia 19-24 tahun sesuai anjuran Kemenkes 2019.

Bagi penelitian selanjutnya, sekiranya perlu melakukan penelitian yang menyangkut semua faktor-faktor yang dapat mempengaruhi persentase lemak tubuh seperti aktivitas fisik, dan lain-lain.

\section{UCAPAN TERIMA KASIH}

Mengucapkan terimakasih yang sebesar-besarnya, kepada dokter-dokter yang selalu membimbing saya dalam melakukan penelitian ini, semoga penelitian ini dapat bermanfaat buat kita semua.

\section{DAFTAR PUSTAKA}

1. Kementerian Kesehatan RI. Laporan Hasil Riset Kesehatan Dasar 2013. Ris Kesehat Dasar 2013. Published online 2013.

2. World Health Organization. Global recommendations on physical activity for health. Geneva WHO Press. Published online 
2010. doi:10.1080/11026480410034349

3. Rahma Pramudita S, Rahayu Nadhiroh S. GAMBARAN AKTIVITAS SEDENTARI DAN TINGKAT KECUKUPAN GIZI PADA REMAJA GIZI LEBIH DAN GIZI NORMAL. Vol 12.; 2017. https://ejournal.unair.ac.id/MGI/article/view/3414

4. Wirawan, Novita N. Sensitifitas dan Spesifisitas IMT dan Lingkar PinggangPanggul dalam Mengklasifikasikan Kegemukan pada Wanita. Indones J Hum Nutr. 2016;3(1). doi:10.21776/ub.ijhn.2016.003.01.6

5. Atkinson RL. Etiologies Of Obesity in The Management of Eating The Sholders and Obesity. 2nd ed. Totoa: Humana Pres, Inc; 2005.

6. Murbawani EA, Firiana L. Hubungan Persen Lemak Tubuh Dan Aktivitas Fisik Dengan Tingkat Kesegaran Jasmani Remaja Putri. Vol 5. Universitas Diponegoro; 2017. doi:10.14710/JNH.5.2.2017.69-84

7. Nina Wijayanti D, Sukmaningtyas H, Yudi Fitranti D. KESESUAIAN METODE PENGUKURAN PERSENTASE LEMAK TUBUH SKINFOLD CALIPER DENGAN METODE BIOLECTRICAL IMPEDANCE ANALYSIS. DIPONEGORO Med J (JURNAL Kedokt DIPONEGORO). 2018;7(2):1504-1510.

https://ejournal3.undip.ac.id/index.php/medic o/article/view/21468

8. Sudargo T, LM HF, Rosiyanti F, Kusmayanti NA. Pola Makan dan Obesitas. In: Gadjah Mada University PRESS. ; 2014.

9. Tinta I, Sumarni S. HUBUNGAN OBESITAS SENTRAL DENGAN MEMORI JANGKA PENDEK MAHASISWA FAKULTAS KEDOKTERAN UNIVERSITAS TADULAKO. Healthy Tadulako J (Jurnal Kesehatan Tadulako). 2019;5(3):45. doi:10.22487/j25020749.2019.v5.i3.14056
10. Surbakti S. Asupan Bahan Makanan Dan Gizi Bagi Atlet Renang. J Ilmu Keolahragaan. 2010;8(2):108-122.

11. Yussac MAA, Cahyadi A, Putri AC, et al. Prevalensi Obesitas pada Anak Usia 4-6 Tahun dan Hubungannya dengan Asupan Serta Pola Makan. Maj Kedokt Indon. 2007;57(2):2017.

12. Freeman LR, Haley-Zitlin V, Rosenberger DS, Granholm AC. Damaging effects of a high-fat diet to the brain and cognition: A review of proposed mechanisms. Nutr Neurosci. 2014;17(6):241-251. doi:10.1179/1476830513Y.0000000092

13. Diniyyah SR, Nindya TS. Asupan Energi, Protein dan Lemak dengan Kejadian Gizi Kurang pada Balita Usia 24-59 Bulan di Desa Suci, Gresik. Amerta Nutr. 2017;1(4):341. doi:10.20473/amnt.v1i4.2017.341-350

14. P2PTM Kemenkes RI. Pengaruh Konsumsi Lemak Berlebihan Terhadap Penyakit Tidak Menular. Direktorat P2PTM Kemenkes RI. Published 2019. http://www.p2ptm.kemkes.go.id/infographic$\mathrm{p} 2 \mathrm{ptm} /$ stroke/page/3/pengaruh-konsumsilemak-berlebihan-terhadap-penyakit-tidakmenular

15. Amelia IN, Syauqy A. HUBUNGAN ANTARA ASUPAN ENERGI DAN AKTIVITAS FISIK DENGAN PERSEN LEMAK TUBUH PADA WANITA PESERTA SENAM AEROBIK. $J$ Nutr Coll. 2014;3(1):200-205. doi:10.14710/jnc.v3i1.4559

16. Rachmawati PA, Murbawani EA. HUBUNGAN ASUPAN ZAT GIZI, AKTIVITAS FISIK, DAN PERSENTASE LEMAK TUBUH DENGAN GANGGUAN SIKLUS MENSTRUASI PADA PENARI. $J$ Nutr Coll. 2015;4(1):39-49. doi:10.14710/jnc.v4i1.8619 